\title{
TATANAN NILAI SOSIAL BUDAYA DAN MODRENISASI MASYARAKAT HINDU BALI DI DESA TAMBAN LUAR KECAMATAN BATAGUH KABUPATEN KAPUAS
}

Oleh

I Wayan Dana

\begin{abstract}
Abstrak
Modernisasi berdampak terhadap perbuahan sosial budaya suatu masyarakat . Dampak modernisasi terhadap perubahan sosial budaya masyarakat dapat berupa meningkatnya produktivitas masyarakat dalam berbagai bidang.Modernisasi terjadi dominan pada bidang teknologi yang mampu meningkatkan hasil suatu produk secara kuantitatif. Namun secara kualitatif peningkatan teknologi ini juga berdampak pada ketergantungan Indonesia terhadap perusahaan asing dalam pengadaan teknologi tersebut. Sebagian besar masyarakat Indonesia adalah petani yang masih belum siap menghadapi modernisasi yang terjadi, sehingga kemampuan sumber daya petani perlu untuk ditingkatkan. Selain itu, peningkatan teknologi pertanian yang terjadi belum sama besar dengan penigkatan sumber daya petani. Modernisasi yang terjadi pun sulit untuk dibendung dan memang harus terjadi. Oleh sebab itu, untuk membangun pertanian pemerintah Indonesia perlu lebih terfokus pada pengembangan sumber daya masyarakat dalam hal pemahaman perkembangan teknologi tersebut.. Metode yang digunakan dalam pembuatan makalah ini adalah metode kuantitatif. Makalah ini dibuat dengan menggunakan data primer dan sekunder yang merupakan data yang diperoleh dari narasumber langsung di lapangan dan dokumen tertulis baik yang berupa tulisan ilmiah maupun buku.
\end{abstract}

Kata Kunci : Modernisasi, Perubahan Sosial Budaya

${ }^{*}$ Dosen pada Fakultas Dharma Sastra IAHN-TP Palangka Raya

\section{PENDAHULUAN}

Seiring berjalannya waktu budaya suatu masyarakatn yang mendiami sebuah wilayah yang ada di Kalimantan Tengah,tak terkecuali masyarakat Bali desa tamban luar kabupaten Kapuas sedikit demi 
sedikit mengalami perubahan yang di karenakan derasnya arus globalisasi yang di dominasi oleh budaya luar. Banyak yang melontarkan dua hal yang susah untuk di tarik benang merah dari permasalahan tersebut oleh pakarpakar kebudayan yang juga merupakan sosiolog asal Kenya,mengatakan bahwa globalisasi dalam bentuk yang alami akan meninggikan berbagai budaya dan nilai-nilai budaya. Dalam proses alami ini, setiap suku bangsa akan berusaha menyesuaikan budaya mereka dengan perkembangan baru sehingga mereka dapat melanjutkan kehidupan dan menghindari kehancuran. Tetapi, menurut Simon Kimoni, dalam proses ini, negara-negara harus memperkokoh dimensi budaya mereka dan memelihara struktur nilainilainya agar tidak dieliminasi oleh budaya asing.Modrenisasi berusaha untuk menghancurkan tradisi dan bahasa pribumi sehingga bangsa-bangsa tersebut kebingungan dalam upaya mencari indentitas budaya nasionalnya,dalam bentuk yang lebih luas dengan nama globalisasi.

Perubahan budaya yang terjadi di dalam masyarakat tradisional, yakni perubahan dari masyarakat tertutup menjadi masyarakat yang lebih terbuka, dari nilai-nilai yang bersifat homogen menuju pluralisme nilai dan norma social merupakan salah satu dampak dari adanya globalisasi. Ilmu pengetahuan dan teknologi telah mengubah dunia secara mendasar. Komunikasi dan sarana transportasi internasional telah menghilangkan batas-batas budaya setiap bangsa. Kebudayaan setiap bangsa cenderung mengarah kepada globalisasi dan menjadi peradaban dunia sehingga melibatkan manusia secara menyeluruh. Belum lagi siaran tv internasional yang bisa ditangkap melalui parabola yang kini makin banyak dimiliki masyarakat Indonesia. Sementara itu, kesenian-kesenian populer lain yang tersaji melalui kaset, vcd, dan dvd yang berasal dari manca negara pun makin marak kehadirannya di tengah-tengah kita. Fakta yang demikian memberikan bukti tentang betapa negara-negara penguasa teknologi mutakhir telah berhasil memegang kendali dalam globalisasi budaya khususnya di negara ke tiga. Peristiwa transkultural seperti itu mau tidak mau akan berpengaruh terhadap keberadaan kesenian kita. Padahal 
kesenian tradisional kita merupakan bagian dari khasanah kebudayaan nasional yang perlu dijaga kelestariannya. Di saat yang lain dengan teknologi informasi yang semakin canggih seperti saat ini, kita disuguhi oleh banyak alternatif tawaran hiburan dan informasi yang lebih beragam, yang mungkin lebih menarik jika dibandingkan dengan kesenian tradisional kita. Dengan parabola masyarakat bisa menyaksikan berbagai tayangan hiburan yang bersifat mendunia yang berasal dari berbagai belahan bumi. Kondisi yang demikian mau tidak mau membuat semakin tersisihnya kesenian tradisional Indonesia dari kehidupan masyarakat Indonesia yang sarat akan pemaknaan dalam masyarakat Indonesia. Misalnya saja bentuk-bentuk ekspresi kesenian etnis Indonesia, baik yang rakyat maupun istana, selalu berkaitan erat dengan perilaku ritual masyarakat pertanian, yang kesemua itu sedikit demi sedikit akan tersingkir.

Pesatnya laju teknologi informasi atau teknologi komunikasi telah menjadi sarana difusi budaya yang ampuh, sekaligus juga alternatif pilihan hiburan yang lebih beragam bagi masyarakat luas. Akibatnya masyarakat tidak tertarik lagi menikmati berbagai seni pertunjukan tradisional yang sebelumnya akrab dengan kehidupan mereka. Selain bidang seni juga semakin terkikisnya budaya gotong royong diakibatkan pengaruh globalisasi dimana dijaman global seperti sekarang ini orang selalu berpikir prakmatis dan semuanya dinilai dengan uang, sehingga budaya gotong royongpun hampir punah. Demikian juga halnya budaya belum bahadat sudah mulai bergeser pada budaya pergaulan bebas, sehingga nilai-nilai kesopanan banyak diabaikan khusunya bagi anak-anak muda sekarang.

\section{PEMBAHASAN}

\section{A. Modernisasi}

Modernisasi adalah suatu proses transformasi masyarakat yang menuntut terjadinya perubagan masyarakata dalam berbagai aspek.. Menurut (Sunito dan Sunito 2003 dalam Koentjaraningrat 1975) Modernisasi sebagai proses mengembangkan sikap mental berorientasi ke masa depan, berhasrat mengeksploitasi lingkungan, menilai tinggi hasil karya manusia, dan sikap 
lain yang sejenis. Namun Modernisasi juga dapat diartikan sebagai perubahan-perubahan masyarakat yang bergerak dari keadaan yang tradisional atau dari masyarakat pra modern menuju kepada suatu masyarakat yang modern. Masyarakat modern adalah masyarakat yang sebagian besar warganya mempunyai orientasi nilai budaya yang terarah ke kehidupan dalam peradaban masa kini. Pada umumnya masyarakat modern tinggal di daerah perkotaan, sehingga disebut masyarakat kota. Soerjono Soekanto mengemukakan bahwa sebuah modernisasi memiliki syarat-syarat tertentu, yaitu sebagai berikut :• Cara berpikir yang ilmiah yang berlembaga dalam kelas penguasa ataupun masyarakat. $\bullet$ Sistem administrasi negara yang baik, yang benar-benar mewujudkan birokrasi.• Adanya sistem pengumpulan data yang baik dan teratur yang terpusat pada suatu lembaga atau badan tertentu. $\bullet$ Penciptaan iklim yang menyenangkan dan masyarakat terhadap modernisasi dengan cara penggunaan alat-alat komunikasi massa. Tingkat organisasi yang tinggi yang di satu pihak berarti disiplin, sedangkan di lain pihak berarti pengurangan

Schrool (1980) menguraikan proses modernisasi secara lebih rinci sebagai berikut :

1. Perubahan yang ada sebagai proses transformasi masyarakat dari masyarakat tradisional ke masyarakat modern

2. Sebagai tumbuhnya industrialisasi seperti yang terjadi di Barat

3. Sebagai tumbuhnya ilmu pengetahuan

4. Sebagai usaha mengejar ketertinggalan dari negara industri maju

5. Secara politis merupakan proses bertambahnya pengaruh dan tugas birokrasi negara, dan bertambahnya ciri rasionalisme organisasi

6. Secara sosiologis dan antropologis sebagai proses diferensiasi sosial dan pembesaran skala.

Modernisasi pertanian adalah suatu bentuk perubahan-perubahan masyarakat tani yang bergerak dari suatu keadaan yang pertanian yang masih tradisional atau dari masyarakat pra modern menuju kepada suatu pertanian yang modern. Untuk mewujudkan pertanian yang modern 
menurut Salikin (2003) dibutuhkan kualitas sumberdaya petani dan nelayan yang menguasai ilmu dan teknologi pertanian, memiliki jiwa entrepreneurship, dan siap menghadapai kompetisi bisnis yang lokal maupun internasional. Perubahan-perubahan sosial petani akibat dari modernisasi adalah dengan diperkenalkannya mesin-mesin, seperti mesin penuai dan traktor tangan telah menghilangkan mata pencaharian penduduk yang selama ini mendapatkan upah dari menuai.

Perubahan Sosial Budaya Menurut (Sunito dan Sunito 2003 dalam Selo Soemarjan 1981) perubahan sosial adalah gejala perubahan dalam lembaga-lembaga kemasyarakatan yang mempengaruhi sistem sosialnya, termasuk di dalamnya perubahan-perubahan dalam nilai-nilai, sikap-sikap, dan pola-pola perikelakuan di antara kelompok-kelompok di dalam suatu masyarakat. Perubahan sosial yang terjadi cenderung terjadi dari tahap sederhana ke tahap yang lebih kompleks, dari tahap masyarakat sederhana (homogen) ke masyarakat yang lebih terdiferensiasi (heterogen). Perubahan sosial juga sangat berhubungan dengan pembangunan yang terjadi. Pembangunan adalah proses perubahan sosial masyarakat menuju yang lebih modern atau lebih sejahtera.

Dibawah ini akan dibahas empat faktor sumber perubahan yaitu lingkungan alam, kependudukan, inovasi dan difusi (Sunito dan Sunito 2003 dalam Calhoun, et al., 1994)

Lingkungan alam memberi peluang bagi perubahan sosial sekaligus menjadi pembatas bagi usaha manusia dalam mengusahakan perubahan.

Lingkungan alam membentuk dan mempengaruhi perubahan social melalui berbagai jalan.Jumlah, kepadatan, pertumbuhan dan komposisi penduduk mempunyai pengaruh besar terhadap kehidupan sosial dan organisasi sosial suatu masyarakat. Struktur penduduk merupakan salah satu aspek yang paling penting dan mendasar dari struktur sosial. Struktur penduduk mencangkup tidak saja jumlah dari suatu kelompok (dibanding kelompok lain) dalam populasi tetapi juga bagaimana sebaran geografis dan kategori sosialnya. Struktur penduduk berubah karena tindakan sosial dan 
perubahan pola budaya. Perubahan kependudukan ini berintegrasi fungsional dengan berbagai aspek kehidupan sosial lainya Inovasi didefinisikan sebagai pengembangan (sosial) dan pelembagaan dari ide-ide baru, produk baru, proses dan struktur baru. Difusi didefinisikan sebagai penyebaran inovasi-inovasi baru dari satu masyarakat ke masyarakat yang lain.Budaya atau kebudayaan berasal dari bahasa sangsakestra yaitu budhayah, yang merupakan bentuk jamak dari buddhi (budi atau akal), diartikan sebagai hal-hal yang berkaitan dengan budi dan akal manusia. Dalam bahasa Inggris, budaya dfisebut dengan culture yang berasal dari kata latin colere, yang bermakna mengolah atau mengerjakan. Kata culture terkadang juga diartikan sebagai "kultur" dalam bahasa Indonesia. Menurut (Sunito dan Sunito 2003 dalam Soemardjan dan Soemardi 1964) Kebudayaan sebagai semua hasil karya, rasa dan cipta masyarkat. Menurut Raharjo (1999) Perubahan kultural (kebudayaan) adalah perubahan kebudayaan masyarakat desa dari pola tradisional menjadi bersifat modern.

\section{Teori-Teori Perubahan Kebudayaan}

\section{Teori Evolusi}

Teori evolusi menggambarkan bahwa perubahan kebudayaan terjadi secara perlahan-lahan dan bertahap. Setiap masyarakat mengalami proses evolusi yang berbeda-beda. Oleh karena itu, masing-masing masyarakat menunjukkan kebudayaan yang berbeda-beda. Salah satu masyarakat dikenal telah maju, sedangkan masyarakat yang lain masih dianggap atau tergolong sebagai masyarakat yang belum maju. Dalam teori evolusi, kemudian dibagi menjadi dua:

\section{a. Teori Evolusi Universal}

Sebuah kebudayaan yang ada dalam sebuah komunitas masyarakat manusia adalah dampak atau hasil hasil dari pemakaian atau penggunaan energi dan teknologi yang mereka gunakan dalam kehidupan mereka pada fase-fase perkembangannya. Dengan rumusan yang disebutnya sebagai "hukum" evolusi kebudayaan ini, White sampai pada sebuah kesimpulan bahwa terjadinya sebuah evolusi kebudayaan dalam sebuah komunitas merupakan hasil dari mengemukanya perubahan dalam sistem yang melakukan 
transformasi energi dengan bantuan teknologi yang ada saat itu. Dengan demikian, dapat dikatakan bahwa dalam teori mengenai evolusi kebudayaan ini terdapat beberapa konsep baru yang diketengahkan White, yaitu thermodinamika (sistem yang melakukan transformasi energi), energi dan transformasi.

\section{b. Teori Evolusi Multilinier}

Menurut teori multilinier, terjadinya evolusi kebudayaan berhubungan erat dengan kondisi lingkungan, dimana setiap kebudayaan memiliki culture core, berupa teknologi dan organisasi kerja. Dengan demikian, terjadinya evolusi dalam sebuah kebudayaan ditentukan oleh adanya interaksi yang terjalin antara kebudayaan tersebut dengan lingkungan yang ada di dalamnya. Seperti halnya teori yang dikemukakan oleh White di atas, teori multilinier juga memunculkan konsep-konsep baru yang belum pernah ada sebelumnya, yaitu lingkungan, culture core, adaptasi dan organisasi kerja.

\section{Teori Difusi}

Teori difusi kebudayaan dimaknai sebagai persebaran kebudayaan yang disebabkan adanya migrasi manusia. Perpindahan dari satu tempat ke tempat lain, akan menularkan budaya tertentu. Hal ini akan semakian tampak dan jelas kalau perpindahan manusia itu secara kelompok dan atau besar-besaran, di kemudian hari akan menimbulkan difusi budaya yang luar biasa. Setiap ada persebaran kebudayaan, di situlah terjadi penggabungan dua kebudayaan atau lebih. Akibat pengaruh kemajuan teknologikomunikasi, juga akan mempengaruhi terjadinya difusi budaya. Keadaan ini memungkinkan kebudayaan semakin kompleks dan bersifat multikultural.

Perubahan kebudayaan yang dijelaskan di atas merupakan akibat dari berbagai macam faktor yang terjadi dalam kehidupan masyarakat, antara lain:

1. Adanya penemuan/inovasi baru yang bermanfaat dan dapat diterima oleh masyarakat kebudayaan.

2. Penyebaran unsur kebudayaan dari masyarakat satu ke lainnya. 
3. Kehilangan kebudayaan, diakibatkan suatu masyarakat secara terusmenerus menerima inovasi baru yang menggantikan unsur-unsur kebudayaan asli dari generasi pendahulu.

4. Akulturasi.

5. Adanya perubahan kebudayaan yang sebagai akibat dari suatu usaha perubahan oleh kelompok masyarakat kebudayaan lain (pembunuhan kebudayaan/genocide). Hal ini sering disebabkan oleh konflik politik.

\section{B. Eksistensi Sosial Budaya Masyarakat Bali Desa Tamban Luar}

\section{Kabupaten Kapuas}

Eksistensi sosisl budaya mengandung pengengertian yaitu (1) pikiran; akal budi; (2) adat istiadat; menyelidiki bahasa (3) sesuatu mengenai kebudayaan yang sudah berkembang (beradab, maju); (4) sesuatu yg sudah menjadi kebiasaan yang sudah sukar diubah. Karena demikian luasnya, maka guna keperluan analisa konsep kebudayaan itu perlu dipecah lagi kedalam unsur-unsurnya. Unsur-unsur terbesar yang terjadi karena pecahan tahap pertama disebut "unsur-unsur kebudayaan yng universal"' dan merupakan unsur-unsur yang pasti bisa ditemukan di semua kebudayaan di dunia, baik yang hidup dalam masyarakat pedesaan yang kecil terpencil maupun dalam masyarakat perkotaan yang besar dan komplex. Unsur-unsur universal itu, yang sekalian merupakan isi dari semua kebudayaan yang ada didunia ini, adalah (1) sistem religi dan upacara keagamaan; (2) sistem organisasikemasyarakatan; (3) sistem pengetahuan; (4) Bahasa; (5) Kesenian; (6) Sistem mata pencaharian hidup; (7) Sistem teknologi dan peralatan (Koentjaraningrat, 2008:2).

Koentjoraningrat lebih lanjut menguraikan bahwa kebudayaan itu mempunyai paling sedikit tiga wujud yaitu:

wujud kebudayaan sebagai suatu kompleks dari idée-idee, gagasan nilainilai, norma-norma, peraturan-peraturan dan sebagainya.

Wujud kebudayaan sebagai suatu kompleks aktivitas kelakuan berpola dari manusia dalam masyarakat.

Wujud kebudayaan sebagai benda-benda hasil karya manusia. 
Wujud pertama adalah wujud idel dari kebudayaan. Sefatnya abstrak, tek dapat diraba atau difoto. Lokasinya ada didalam kepala-kepala atau dengan perkataan lain dalam alam pikiran dari warga masyarakat dimana kebudayaan yang bersangkutan itu hidup. Kalau warga masyarakat tadi menyampaikan gagasan mereka itu dalam tulisan, maka lokasi kebudayaan ideel sering berada dalam karangan dan buku-buku hasil karya para penulis warga masyarakat yang bersangkutan. Sekarang kebudayaan idel banyak tersimpan dalam disk, tape, arsip, koleksi mocrofilm dan microfish, kartucomputer, disk, silinder, dan tape computer.

Kebudayaan idel ini dapat kita sebut tata kelakuan atau secara singkat adat dalam arti khusus, atau adat istiadat dalam bentuk jamaknya. Sebutan tata kelakuan itu maksudnya menunjukan bahwa kebudayaan idel itu biasanya juga berfungsi sebagai tata-kelakuan yang mengatur, mengendalikandan memberi arah kepada kelakuan dan perbuatan manusia dalam masyarakat.

Wujud kedua dari kebudayaaqn yang sering disebut sistem sosial, mengenai kelakuan berpola dari manusia itu sendiri. Sistem sosial ini terdiri dari aktivitas-aktivitas manusia-manusia yang berinteraksi, berhubungan, serta bergaul satu dengan lain, yang dari detik ke detik, daari hari ke hari, dan dari tahun ke tahun selalu mengikuti pola-pola tertentu yang berdasarkan adat tata-kelakuan. Sebagai rangkaian aktivitas manusia-manusia dalam suatu masyarakat, maka sistem sosial itu bersifat konkret, terjadi disekeliling kita sehari hari-hari, bisa diobservasi, difoto dan didokumentasikan.

Wujud ketiga dari kebudayaan disebut kebudayaan fisik dan memerlukan keterangan banyak. Karena merupakan seluruh total dari hasil fisik dari aktivitas, perbuatan, dan karya semua manusia dalam masyarakat, maka sifat paling konkret, dan berupa benda-benda atau hal-hal yang dapat diraba, dilihat, dan difoto. Ada benda-benda yang amat besar seperti suatu pabrik baja; ada benda-benda yang amat kompleks dan sophisticated seperti suatu compoter berkapasitas tinggi; atau benda-benda yang besar dan 
bergerak seperti perahu tangki minyak; ada benda-benda yang besar dan indah seperti candi yang indah (Koentjoraningrat, 2008:5).

Kehadiran globalisasi tentunya membawa pengaruh bagi eksietensi budaya termasuk budaya masyarakat Bali di Kebupaten Kapuas . Pengaruh tersebut meliputi dua sisi yaitu pengaruh positif dan pengaruh negatif. Pengaruh globalisasi di berbagai unsur-unsur kebudayaan seperti sistem religi dan upacara keagamaan; sistem organisasikemasyarakatan; sistem pengetahuan; Bahasa; Kesenian; Sistem mata pencaharian hidup; Sistem teknologi dan peralatan, akan mempengaruhi keberadaan suatu budaya.

Pengaruh posiif dari globalisasi terhadap budaya kita dapat meniru pola berpikir yang baik seperti etos kerja yang tinggi dan disiplin dan Iptek dari bangsa lain yang sudah maju untuk meningkatkan kemajuan bangsa yang pada akhirnya memajukan bangsa.

Pengaruh negatif globalisasi terhadap budaya mampu meyakinkan masyarakat Indonesia bahwa liberalisme dapat membawa kemajuan dan kemakmuran. Sehingga tidak menutup kemungkinan berubah arah dari ideologi Pancasila ke ideologi liberalisme. Dari globalisasi aspek ekonomi, hilangnya rasa cinta terhadap produk dalam negeri karena banyaknya produk luar negeri (seperti Mc Donald, Coca Cola, Pizza Hut,dll.) membanjiri di Indonesia. Dengan hilangnya rasa cinta terhadap produk dalam negeri menunjukan gejala berkurangnya rasa nasionalisme masyarakat kita terhadap bangsa Indonesia.

Mayarakat kita khususnya anak muda banyak yang lupa akan identitas diri sebagai bangsa Indonesia, karena gaya hidupnya cenderung meniru budaya barat yang oleh masyarakat dunia dianggap sebagai kiblat. Mengakibatkan adanya kesenjangan sosial yang tajam antara yang kaya dan miskin, karena adanya persaingan bebas dalam globalisasi ekonomi. Hal tersebut dapat menimbulkan pertentangan antara yang kaya dan miskin yang dapat mengganggu kehidupan nasional bangsa. 
Munculnya sikap individualisme yang menimbulkan ketidakpedulian antarperilaku sesama warga. Dengan adanya individualisme maka orang tidak akan peduli dengan kehidupan orang lain. Budaya gotong royong sudah mulai luntur, bahkan hampir sulit ditemui di kebupaten namun tidak demikian yang terjadi di didesa Tamban luar masyarakatnya tetap mempertahankan sikap gotong royong yang diwariskan oleh para leluhutnya. Meskipun ada beberapa kegiatan/pekerjaan diupahkan seperti membuat rumah misalnya dulu dikerjakan secara gotong royong namun sekarang semua buruh yang mengerjakan .

DAMPAK MODERNISASI TERHADAP PERUBAHAN SOSIAL BUDAYA MASYARAKAT TANI DI DESA TAMBAN LUAR KABUPATEN KAPUAS

Setiap negara akan lebih mudah mengalami modernisasi pada era globalisasi ini. Modernisasi yang terjadi pun terjadi di berbagai bidang. Salah satunya terjadi pada bidang pertanian. Modernisasi yang terjadi di bidang pertanian biasa disebut Modernisasi Pertanian. Modernisasi pertanian terjadi ditandai dengan perubahan pola-pola kegiatan pertanian dari yang tradisional menjadi yang lebih modern. Modernisasi pertanian dominan terjadi dalam hal peningkatan teknologi, seperti penggunaan bibit unggul, pupuk organik, mesin-mesin pengolah pertaanian dan yang lainya. Namun Modernisasi pertanian tidak hanya terjadi pada kemajuan teknologi saja, Pola-pola kelembagaan yang membantu produktivitas pertanian juga banyak terjadi diantaranya; Organisasi organisasi pertanian seperti Kelompok tani dan yang lainya. Selain itu banyak juga kebijakan kebijakan pemerintah yang mendorong terjadinya modernisasi pertanian. Masyarakat desa Tamban Luar kecamatan Bataguh saat sekarang telah menngunakan alat alat modern untuk mengolah lahan prtanian ataupun perkebunan mereka. Dulunya masyarakat mencangkul sawahnya kini mereka telah menggunakan trakror untuk mengolah lahannya. Sehingga waktu pengolahanlahannya menjadi lebih singkat. Pengolahan lahan semacam ini biasanya dilakukan berkelompok beranggotakan 5 sampai 8 orang, dimana system pengerjaanya bergantian dari orang pertama sampai yang kedelapan. 
Demikian pula untuk masa penanamannya dilakukan berkelompok sesuai kesepakatan.

Namun modernisasi pertanian ini menimbulkan paradigma pembangunan pertanian yang baru yaitu Paradigma Modernisasi Pertanian“Paradigma modernisasi pertanian yang bertujuan untuk mengubah sektor pertanian tradisional menjadi sektor pertanian modern yang mampu meningkatkan produksi sektor pertanian, merupakan paradigma yang menjadi rujukan bagi semua pemerintahan di negara-negara yang sedang berkembang dalam membangun sektor pertanian mereka . Paradigma modernisasi pertanian tersebut dikenal dengan revolusi hijau " (Soetrisno 1999). Paradigma Modernisasi Pertanian tentu bertujuan untuk meningkatkan produktivitas segala bentuk kegiatan pertanian. Perkembangan yang terjadi dalam beberapa tahun terakhir menunjukan produktivitas pertanian yang lebih produktif Kita dapat melihat produktivitas Petani Padi di Provinsi Kalimantan khususnya Kalimantan Tengah tang y meningkat . Dampak Modernisasi pertanian salah satunya dapat meningkatkan produktivitas kegiatan pertanian. Dalam lima tahun produktivitas petani padi di Indonesia meningkat dari 48,94\% pada tahun 2008 hingga 51,36\% di tahun 2012. Modernisasi Pertanian juga tidak hanya berdampak dalam hal produktivitas pertanian. Modernisasi pertanian juga berdampak terhadap pola pikir masyrakat tani. Modernisasi pertanian yang dominan terjadi dalam bidang teknologi menimbulkan sedikit masalah bagi masyarakat tani. Tingkat pendidikan petani yang masih rendah membuat petani sulit untuk menerima teknologi yang ada akibatnya petani menjadi sangat bergantung terhadap inovasi teknologi yang diberikan. Jika tidak adanya inovasi teknologi aka petani tidak bisa menyelsaikan permasalahannya.Modernisasi pertanian dalam arti pemakaian teknologi seperti penggunaan mesin dan pupuk kimiawi menyebabkan ongkos produksi pertanian meningkat menjadi mahal sedangkan harga produk yang dijual dari petani masih rendah. Hal ini dapat menimbulkan ketimpangan sosial diantara masyarakat tani. Para petani yang mempunyai teknologi dapat mempunyai 
kesejahteraan yang jauh lebih baik dari petani yang masih belum mempunyai teknologi. Petani yang tidak mempunyai teknologi kelangsungan kehidupannya bergantung pada petani yang mempunyai berbagai teknologi karena memiliki kekuatan ekonomi yang lebih baik. Masalah yang diakibatkan dari pengembangan teknologi pertanian di Indonesia tidak hanya demikian. Lingkungan pertanian lain yang berubah juga munculnya perusahaan yang memegang monopoli teknologi pertanian. Negara-negara yang mengembangkan dan memegang kendali dalam bidang teknologi pertanian justru bukan dari negara Indonesia melainkan dari negara asing seperti Amerika, Jepang dan yang lainya. Menurut Soetrisno (1999) "semua perubahan tersebut akan dapat mengancam perkembangan sektor pertanian di negara-negara yang sedang berkembang, apabila pemerintah negara-negara tersebut tidak mampu menciptakan paradigma baru dalam pembangunan pertanian".

\section{Kesimpulan}

Modernisasi adalah proses perubahan sosial masyarakat dari suatu keadaan yang pra modern menjadi suatu keadaan yang modern. Modernisasi pertanian memiliki arti sebagai bentuk sebuah pembangunan pertanian yang menjadikan suatu pertanian yang tradisional menjadi pertanian yang modern. Modernisasi pertanian yang terjadi pun didominasi oleh pengembangan teknologi. Modernisai pertanian ini menjadi suatu paradigma baru untuk membangun sektor pertanian. Hal ini berdampak terhadap kondisi perubahan sosial masyarakat tani. Secara umum dapat dinyatakan bahwa petani (padi) di Indonesia semakin produktif karena adanya modernisasi pertanian ini. Dalam jangka waktu lima tahun terakhir produktivitas petani padi di Indonesia meningkat dari $48,94 \%$ pada tahun 2008 hingga 51,36\% di tahun 2012. Namun hal ini tidak selalu berdampak manis bagi masyarakat tani. Kondisi pendidikan masyarakat tani yang masih rendah menjadikan teknologi yang masuk sulit diterima dan digunakan bagi petani. Selain itu, Terjadi ketimpangan sosial antara petani "kaya" yang mempunyai sumberdaya tekonologi yang lebih baik dibandingkan dengan 
petani "miskin" yang tidak mempunyai teknologi yang cukup baik. Secara global modernisasi pertanian ini berdampak kurang menguntungkan bagi Indonesia karena perusahaan pengembang teknologi pertanian justru didominasi oleh perusahaan asing akibatnya Indonesia masih bergantung terhadap pihak luar dalam pengembangan teknologi pertanian.Gaung modrenisasi, yang sudah mulai terasa sejak akhir abad ke-20, telah membuat masyarakat dunia, termasuk bangsa Indonesia harus bersiap-siap menerima kenyataan masuknya pengaruh luar terhadap seluruh aspek kehidupan bangsa. Salah satu aspek yang terpengaruh adalah kebudayaan. Arus modrenisasi/globalisasi saat ini telah menimbulkan pengaruh terhadap perkembangan budaya bangsa Indonesia. Derasnya arus informasi dan telekomunikasi ternyata menimbulkan sebuah kecenderungan yang mengarah terhadap memudarnya nilai-nilai pelestarian budaya. Perkembangan 3T (Transportasi, Telekomunikasi, dan Teknologi) mengkibatkan berkurangnya keinginan untuk melestarikan budaya negeri sendiri. Budaya Indonesia yang dulunya ramah-tamah, gotong royong dan sopan berganti dengan budaya barat, misalnya pergaulan bebas.

Proses saling mempengaruhi adalah gejala yang wajar dalam interaksi antar masyarakat. Melalui interaksi dengan berbagai masyarakat lain, bangsa Indonesia ataupun kelompok-kelompok masyarakat yang mendiami nusantara (sebelum Indonesia terbentuk) telah mengalami proses dipengaruhi dan mempengaruhi. Kemampuan berubah merupakan sifat yang penting dalam kebudayaan manusia. Tanpa itu kebudayaan tidak mampu menyesuaikan diri dengan keadaan yang senantiasa berubah. Perubahan yang terjadi saat ini berlangsung begitu cepat. Hanya dalam jangka waktu satu generasi banyak negara-negara berkembang telah berusaha melaksanakan perubahan kebudayaan, padahal di negara-negara maju perubahan demikian berlangsung selama beberapa generasi. Pada hakekatnya bangsa Indonesia, juga bangsa-bangsa lain, berkembang karena adanya pengaruh-pengaruh luar. Kemajuan bisa dihasilkan oleh interaksi dengan pihak luar, hal inilah yang terjadi dalam proses globalisasi. Oleh 
karena itu, globalisasi bukan hanya soal ekonomi namun juga terkait dengan masalah atau isu makna budaya dimana nilai dan makna yang terlekat di dalamnya masih tetap berarti.. Masyarakat Indonesia merupakan masyarakat yang majemuk dalam berbagai hal, seperti anekaragaman budaya, lingkungan alam, dan wilayah geografisnya. Keanekaragaman masyarakat Indonesia ini dapat dicerminkan pula dalam berbagai ekspresi keseniannya. Dengan perkataan lain, dapat dikatakan pula bahwa berbagai kelompok masyarakat di Indonesia dapat mengembangkan keseniannya yang sangat khas. Kesenian yang dikembangkannya itu menjadi modelmodel pengetahuan dalam masyarakat.

Perubahan budaya yang terjadi di dalam masyarakat tradisional, yakni perubahan dari masyarakat tertutup menjadi masyarakat yang lebih terbuka, dari nilai-nilai yang bersifat homogen menuju pluralisme nilai dan norma social merupakan salh satu dampak dari adanya globalisasi. Ilmu pengetahuan dan teknologi telah mengubah dunia secara mendasar. Komunikasi dan sarana transportasi internasional telah menghilangkan batas-batas budaya setiap bangsa. Kebudayaan setiap bangsa cenderung mengarah kepada globalisasi dan menjadi peradaban dunia sehingga melibatkan manusia secara menyeluruh. Misalnya saja khusus dalam bidang hiburan massa atau hiburan yang bersifat masal, makna globalisasi itu sudah sedemikian terasa. Sekarang ini setiap hari kita bisa menyimak tayangan film di tv yang bermuara dari negara-negara maju seperti Amerika Serikat, Jepang, Korea, dll melalui stasiun televisi di tanah air. Belum lagi siaran tv internasional yang bisa ditangkap melalui parabola yang kini makin banyak dimiliki masyarakat Indonesia. Sementara itu, kesenian-kesenian populer lain yang tersaji melalui kaset, vcd, dan dvd yang berasal dari manca negara pun makin marak kehadirannya di tengah-tengah kita. Fakta yang demikian memberikan bukti tentang betapa negara-negara penguasa teknologi mutakhir telah berhasil memegang kendali dalam globalisasi budaya khususnya di negara ke tiga. Peristiwa transkultural seperti itu mau tidak mau akan berpengaruh terhadap keberadaan kesenian kita. Padahal 
kesenian tradisional kita merupakan bagian dari khasanah kebudayaan nasional yang perlu dijaga kelestariannya. Di saat yang lain dengan teknologi informasi yang semakin canggih seperti saat ini, kita disuguhi oleh banyak alternatif tawaran hiburan dan informasi yang lebih beragam, yang mungkin lebih menarik jika dibandingkan dengan kesenian tradisional kita. Dengan parabola masyarakat bisa menyaksikan berbagai tayangan hiburan yang bersifat mendunia yang berasal dari berbagai belahan bumi. Kondisi yang demikian mau tidak mau membuat semakin tersisihnya kesenian tradisional Indonesia dari kehidupan masyarakat Indonesia yang sarat akan pemaknaan dalam masyarakat Indonesia. Misalnya saja bentuk-bentuk ekspresi kesenian etnis Indonesia, baik yang rakyat maupun istana, selalu berkaitan erat dengan perilaku ritual masyarakat pertanian. Dengan datangnya perubahan sosial yang hadir sebagai akibat proses industrialisasi dan sistem ekonomi pasar, dan globalisasi informasi, maka kesenian kita pun mulai bergeser ke arah kesenian yang berdimensi komersial. Keseniankesenian yang bersifat ritual mulai tersingkir dan kehilangan fungsinya. Sekalipun demikian, bukan berarti semua kesenian tradisional kita lenyap begitu saja. Ada berbagai kesenian yang masih menunjukkan eksistensinya, bahkan secara kreatif terus berkembang tanpa harus tertindas proses modernisasi. Pesatnya laju teknologi informasi atau teknologi komunikasi telah menjadi sarana difusi budaya yang ampuh, sekaligus juga alternatif pilihan hiburan yang lebih beragam bagi masyarakat luas. Akibatnya masyarakat tidak tertarik lagi menikmati berbagai seni pertunjukan tradisional yang sebelumnya akrab dengan kehidupan mereka. Misalnya saja kesenian tradisional wayang orang Bharata, yang terdapat di Gedung Wayang Orang Bharata Jakarta kini tampak sepi seolah-olah tak ada pengunjungnya. Hal ini sangat disayangkan mengingat wayang merupakan salah satu bentuk kesenian tradisional Indonesia yang sarat dan kaya akan pesan-pesan moral, dan merupakan salah satu agen penanaman nilai-nilai moral yang baik, menurut saya. Contoh lainnya adalah kesenian Ludruk yang sampai pada tahun 1980-an masih berjaya di Jawa Timur sekarang ini 
tengah mengalami "mati suri". Wayang orang dan ludruk merupakan contoh kecil dari mulai terdepaknya kesenian tradisional akibat globalisasi. Bisa jadi fenomena demikian tidak hanya dialami oleh kesenian Jawa tradisional, melainkan juga dalam berbagai ekspresi kesenian tradisional di berbagai tempat di Indonesia. Sekalipun demikian bukan berarti semua kesenian tradisional mati begitu saja dengan merebaknya globalisasi. Di sisi lain, ada beberapa seni pertunjukan yang tetap eksis tetapi telah mengalami perubahan fungsi. Ada pula kesenian yang mampu beradaptasi dan mentransformasikan diri dengan teknologi komunikasi yang telah menyatu dengan kehidupan masyarakat, misalnya saja kesenian tradisional "Ketoprak" yang dipopulerkan ke layar kaca oleh kelompok Srimulat. Kenyataan di atas menunjukkan kesenian ketoprak sesungguhnya memiliki penggemar tersendiri, terutama ketoprak yang disajikan dalam bentuk siaran televisi, bukan ketoprak panggung. Dari segi bentuk pementasan atau penyajian, ketoprak termasuk kesenian tradisional yang telah terbukti mampu beradaptasi dengan perubahan zaman. Selain ketoprak masih ada kesenian lain yang tetap bertahan dan mampu beradaptasi dengan teknologi mutakhir yaitu wayang kulit. Beberapa dalang wayang kulit terkenal seperti Ki Manteb Sudarsono dan Ki Anom Suroto tetap diminati masyarakat, baik itu kaset rekaman pementasannya, maupun pertunjukan secara langsung. Keberanian stasiun televisi Indosiar yang sejak beberapa tahun lalu menayangkan wayang kulit setiap malam minggu cukup sebagai bukti akan besarnya minat masyarakat terhadap salah satu khasanah kebudayaan nasional kita. Bahkan Museum Nasional pun tetap mempertahankan eksistensi dari kesenian tradisonal seperti wayang kulit dengan mengadakan pagelaran wayang kulit tiap beberapa bulan sekali dan pagelaran musik gamelan tiap satu minggu atau satu bulan sekali yang diadakan di aula Kertarajasa, Museum Nasional.

Arus globalisasi saat ini telah menimbulkan pengaruh terhadap perkembangan budaya bangsa Indonesia . Derasnya arus informasi dan telekomunikasi ternyata menimbulkan sebuah kecenderungan yang 
mengarah terhadap memudarnya nilai-nilai pelestarian budaya. Perkembangan 3T (Transportasi, Telekomunikasi, dan Teknologi) mengkibatkan berkurangnya keinginan untuk melestarikan budaya negeri sendiri . Budaya Indonesia yang dulunya ramah-tamah, gotong royong dan sopan berganti dengan budaya barat, misalnya pergaulan bebas. Di Tapanuli (Sumatera Utara) misalnya, duapuluh tahun yang lalu, anak-anak remajanya masih banyak yang berminat untuk belajar tari tor-tor dan tagading (alat musik batak). Hampir setiap minggu dan dalam acara ritual kehidupan, remaja di sana selalu diundang pentas sebagai hiburan budaya yang meriah. Saat ini, ketika teknologi semakin maju, ironisnya kebudayaan-kebudayaan daerah tersebut semakin lenyap di masyarakat, bahkan hanya dapat disaksikan di televisi dan Taman Mini Indonesi Indah (TMII). Padahal kebudayaan-kebudayaan daerah tersebut, bila dikelola dengan baik selain dapat menjadi pariwisata budaya yang menghasilkan pendapatan untuk pemerintah baik pusat maupun daerah, juga dapat menjadi lahan pekerjaan yang menjanjikan bagi masyarakat sekitarnya. Hal lain yang merupakan pengaruh globalisasi adalah dalam pemakaian bahasa indonesia yang baik dan benar (bahasa juga salah satu budaya bangsa). Sudah lazim di Indonesia untuk menyebut orang kedua tunggal dengan Bapak, Ibu, Pak, Bu, Saudara, Anda dibandingkan dengan kau atau kamu sebagai pertimbangan nilai rasa. Sekarang ada kecenderungan di kalangan anak muda yang lebih suka menggunakan bahasa Indonesia dialek Jakarta seperti penyebutan kata gue (saya) dan lu (kamu). Selain itu kita sering dengar anak muda mengunakan bahasa Indonesia dengan dicampur-campur bahasa inggris seperti OK, No problem dan Yes', bahkan kata-kata makian (umpatan) sekalipun yang sering kita dengar di film-film barat, sering diucapkan dalam kehidupan sehari-hari. Kata-kata ini disebarkan melalui media TV dalam film-film, iklan dan sinetron bersamaan dengan disebarkannya gaya hidup dan fashion . Gaya berpakaian remaja Indonesia yang dulunya menjunjung tinggi norma kesopanan telah berubah mengikuti perkembangan jaman. Ada kecenderungan bagi remaja putri di kota-kota besar memakai pakaian minim 
dan ketat yang memamerkan bagian tubuh tertentu. Budaya perpakaian minim ini dianut dari film-film dan majalah-majalah luar negeri yang ditransformasikan kedalam sinetron-sinetron Indonesia . Derasnya arus informasi, yang juga ditandai dengan hadirnya internet, turut serta 'menyumbang' bagi perubahan cara berpakaian. Pakaian mini dan ketat telah menjadi trend dilingkungan anak muda. Salah satu keberhasilan penyebaran kebudayaan Barat ialah meluasnya anggapan bahwa ilmu dan teknologi yang berkembang di Barat merupakan suatu yang universal. Masuknya budaya barat (dalam kemasan ilmu dan teknologi) diterima dengan 'baik'. Pada sisi inilah globalisasi telah merasuki berbagai sistem nilai sosial dan budaya Timur (termasuk Indonesia ) sehingga terbuka pula konflik nilai antara teknologi dan nilai-nilai ketimuran.

Peran kebijaksanaan pemerintah yang lebih mengarah kepada pertimbangan-pertimbangan ekonomi daripada cultural atau budaya dapat dikatakan merugikan suatu perkembangan kebudayaan. Jennifer Lindsay (1995) dalam bukunya yang berjudul 'Cultural Policy And The Performing Arts In South-East Asia', mengungkapkan kebijakan kultural di Asia Tenggara saat ini secara efektif mengubah dan merusak seni-seni pertunjukan tradisional, baik melalui campur tangan, penanganan yang berlebihan, kebijakan-kebijakan tanpa arah, dan tidak ada perhatian yang diberikan pemerintah kepada kebijakan kultural atau konteks kultural. Dalam pengamatan yang lebih sempit dapat kita melihat tingkah laku aparat pemerintah dalam menangani perkembangan kesenian rakyat, di mana banyaknya campur tangan dalam menentukan objek dan berusaha merubah agar sesuai dengan tuntutan pembangunan. Dalam kondisi seperti ini arti dari kesenian rakyat itu sendiri menjadi hambar dan tidak ada rasa seninya lagi. Melihat kecenderungan tersebut, aparat pemerintah telah menjadikan para seniman dipandang sebagai objek pembangunan dan diminta untuk menyesuaikan diri dengan tuntutan simbol-simbol pembangunan. Hal ini tentu saja mengabaikan masalah pemeliharaan dan pengembangan kesenian secara murni, dalam arti benar-benar didukung oleh nilai seni yang 
mendalam dan bukan sekedar hanya dijadikan model saja dalam pembangunan. Dengan demikian, kesenian rakyat semakin lama tidak dapat mempunyai ruang yang cukup memadai untuk perkembangan secara alami atau natural, karena itu, secara tidak langsung kesenian rakyat akhirnya menjadi sangat tergantung oleh model-model pembangunan yang cenderung lebih modern dan rasional. Sebagai contoh dari permasalahan ini dapat kita lihat, misalnya kesenian asli daerah Betawi yaitu, tari cokek, tari lenong, dan sebagainya sudah diatur dan disesuaikan oleh aparat pemerintah untuk memenuhi tuntutan dan tujuan kebijakan-kebijakan politik pemerintah. Aparat pemerintah di sini turut mengatur secara normatif, sehingga kesenian Betawi tersebut tidak lagi terlihat keasliannya dan cenderung dapat membosankan. Untuk mengantisipasi hal-hal yang tidak dikehendaki terhadap keaslian dan perkembangan yang murni bagi kesenian rakyat tersebut, maka pemerintah perlu mengembalikan fungsi pemerintah sebagai pelindung dan pengayom kesenian-kesenian tradisional tanpa harus turut campur dalam proses estetikanya. Memang diakui bahwa kesenian rakyat saat ini membutuhkan dana dan bantuan pemerintah sehingga sulit untuk menghindari keterlibatan pemerintah dan bagi para seniman rakyat ini merupakan sesuatu yang sulit pula membuat keputusan sendiri untuk sesuai dengan keaslian (oroginalitas) yang diinginkan para seniman rakyat tersebut. Oleh karena itu pemerintah harus 'melakoni' dengan benar-benar peranannya sebagai pengayom yang melindungi keaslian dan perkembangan secara estetis kesenian rakyat tersebut tanpa harus merubah dan menyesuaikan dengan kebijakan-kebijakan politik. Globalisasi informasi dan budaya yang terjadi menjelang millenium baru seperti saat ini adalah sesuatu yang tak dapat dielakkan. Kita harus beradaptasi dengannya karena banyak manfaat yang bisa diperoleh. Harus diakui bahwa teknologi komunikasi sebagai salah produk dari modernisasi bermanfaat besar bagi terciptanya dialog dan demokratisasi budaya secara masal dan merata. Globalisasi mempunyai dampak yang besar terhadap budaya. Kontak budaya melalui media massa menyadarkan dan 
memberikan informasi tentang keberadaan nilai-nilai budaya lain yang berbeda dari yang dimiliki dan dikenal selama ini. Kontak budaya ini memberikan masukan yang penting bagi perubahan-perubahan dan pengembangan-pengembangan nilai-nilai dan persepsi dikalangan masyarakat yang terlibat dalam proses ini. Kesenian bangsa Indonesia yang memiliki kekuatan etnis dari berbagai macam daerah juga tidak dapat lepas dari pengaruh kontak budaya ini. Sehingga untuk melakukan penyesuaianpenyesuaian terhadap perubahan-perubahan diperlukan pengembanganpengembangan yang bersifat global namun tetap bercirikan kekuatan lokal atau etnis. Globalisasi budaya yang begitu pesat harus diantisipasi dengan memperkuat identitas kebudayaan nasional. Berbagai kesenian tradisional yang sesungguhnya menjadi aset kekayaan kebudayaan nasional jangan sampai hanya menjadi alat atau slogan para pemegang kebijaksanaan, khususnya pemerintah, dalam rangka keperluan turisme, politik dsb. Selama ini pembinaan dan pengembangan kesenian tradisional yang dilakukan lembaga pemerintah masih sebatas pada unsur formalitas belaka, tanpa menyentuh esensi kehidupan kesenian yang bersangkutan. Akibatnya, kesenian tradisional tersebut bukannya berkembang dan lestari, namun justru semakin dijauhi masyarakat. Dengan demikian, tantangan yang dihadapi oleh kesenian rakyat cukup berat. Karena pada era teknologi dan komunikasi yang sangat canggih dan modern ini masyarakat dihadapkan kepada banyaknya alternatif sebagai pilihan, baik dalam menentukan kualitas maupun selera. Hal ini sangat memungkinkan keberadaan dan eksistensi kesenian rakyat dapat dipandang dengan sebelah mata oleh masyarakat, jika dibandingkan dengan kesenian modern yang merupakan imbas dari budaya pop. Untuk menghadapi hal-hal tersebut di atas ada beberapa alternatif untuk mengatasinya, yaitu meningkatkan Sumber Daya Manusia (SDM ) bagi para seniman rakyat. Selain itu, mengembalikan peran aparat pemerintah sebagai pengayom dan pelindung, dan bukan sebaliknya justru menghancurkannya demi kekuasaan dan pembangunan yang 
berorientasi pada dana-dana proyek atau dana-dana untuk pembangunan dalam bidang ekonomi saja.

\section{PENUTUP}

Pengaruh globalisasi disatu sisi ternyata menimbulkan pengaruh yang negatif bagi kebudayaan bangsa Indonesia . Norma-norma yang terkandung dalam kebudayaan bangsa Indonesia perlahan-lahan mulai pudar. Gencarnya serbuan teknologi disertai nilai-nilai interinsik yang diberlakukan di dalamnya, telah menimbulkan isu mengenai globalisasi dan pada akhirnya menimbulkan nilai baru tentang kesatuan dunia. Radhakrishnan dalam bukunya Eastern Religion and Western Though (1924) menyatakan "untuk pertama kalinya dalam sejarah umat manusia, kesadaran akan kesatuan dunia telah menghentakkan kita, entah suka atau tidak, Timur dan Barat telah menyatu dan tidak pernah lagi terpisah. Artinya adalah bahwa antara barat dan timur tidak ada lagi perbedaan. Atau dengan kata lain kebudayaan kita dilebur dengan kebudayaan asing. Apabila timur dan barat bersatu, masihkah ada ciri khas kebudayaan kita? Ataukah kita larut dalam budaya bangsa lain tanpa meninggalkan sedikitpun sistem nilai kita? Oleh karena itu perlu dipertahanan aspek sosial budaya Indonesia sebagai identitas bangsa. Caranya adalah dengan penyaringan budaya yang masuk ke Indonesia dan pelestarian budaya bangsa. Bagi masyarakat yang mencoba mengembangkan seni tradisional menjadi bagian dari kehidupan modern, tentu akan terus berupaya memodifikasi bentuk-bentuk seni yang masih berpolakan masa lalu untuk dijadikan komoditi yang dapat dikonsumsi masyarakat modern. Karena sebenarnya seni itu indah dan mahal. Kesenian adalah kekayaan bangsa Indonesia yang tidak ternilai harganya dan tidak dimiliki bangsa-bangsa asing. Oleh sebab itu, sebagai generasi muda, yang merupakan pewaris budaya bangsa, hendaknya memelihara seni budaya kita demi masa depan anak cucu. 


\section{DAFTAR PUSTAKA}

Adeney, Bernard T. 1995. Etika Sosial Lintas Budaya. Yogyakarta: Kanisius. Al-Hadar Smith,

Koenjaraningrat. 1990. Kebudayaan Mentalitas dan Pembangunan. Jakarta: Gramedia.

Otib Satibi Hidayat. 2000. Metode Pengembangan Moral dan Nilai-Nilai Agama, Jakarta: Universitas Terbuka 